Article

\title{
Outsiders Within: Claiming Discursive Space at National Homelessness Conferences in Canada
}

\author{
Emily Paradis \\ Factor-Inwentash Faculty of Social Work, Toronto University, Ontario, M5S 1V4, Canada; E-Mail: e.paradis@utoronto.ca
}

Submitted: 12 May 2016 | Accepted: 25 August 2016 | Published: 20 October 2016

\begin{abstract}
Homelessness in Canada is a large and growing problem affecting more than 235,000 men, women, youth, and families per year, in urban, suburban, rural and Northern communities. Though it is produced by economic and policy drivers including colonization, income insecurity, and state withdrawal from housing provision, policies on homelessness tend to focus on service provision rather than addressing root causes. This article reviews activist, advocacy, service and policy responses to homelessness in Canada, and in particular, homeless sector conferences. Taking as its starting-point a demonstration at a 2014 national conference on homelessness, it examines these conferences as important sites of governance in which service organizations collaborate in the development and delivery of policy. Conferences' normative culture, and their discursive construction of homelessness as a technical problem, tend to leave unchallenged the prevailing economic, social, political and institutional arrangements that produce homelessness. Recent interventions by people facing homelessness and their allies, though, have claimed discursive space at national homelessness conferences for outsider perspectives and demands. These interventions open possibilities for new alliances, analyses, and tactics that are necessary for ending homelessness.
\end{abstract}

\section{Keywords}

activism; conferences; governance; homelessness; lived experience

Issue

This article is part of the issue "Homelessness and Social Inclusion", edited by Isobel Anderson (University of Stirling, UK), Maša Filipovič Hrast (University of Ljubljana, Slovenia) and Joe Finnerty (University College Cork, Ireland).

(C) 2016 by the author; licensee Cogitatio (Lisbon, Portugal). This article is licensed under a Creative Commons Attribution 4.0 International License (CC BY).

\section{Introduction}

On a chilly, rainy evening in November 2014, dozens of anti-poverty activists marched down a busy street in the business district of Vancouver, British Columbia, on Canada's Pacific coast. Wet placards and banners illuminated by the headlights of passing cars read, 'Housing is a right' and 'Social housing now.' As the marchers turned into the dark courtyard of a luxury hotel, they were greeted by security guards who informed them that this was private property and they would have to leave or police would be called. Undaunted, the activists pressed forward, their chants of 'Homelessness has got to go!' echoing from the walls of the hotel's two towers. The guards rushed inside as the protestors assembled before the hotel's main entrance, and police soon arrived to form a barricade line across the lobby.
Outside in the rain, separated from police by a glass wall of windows and locked doors, speakers addressed the crowd using a portable PA system. Most speakers identified themselves as Indigenous, many identified as having disabilities, and all explicitly spoke from lived experience with homelessness and poverty. They decried the City of Vancouver's failure to take effective action to end homelessness, and its recent eviction of a homeless encampment from a local park. They called for an end to gentrification, displacement, and criminalization of homeless people, and demanded that Indigenous territorial rights be respected, social housing be built and welfare rates be increased.

Things heated up. A guard crushed a protestor's hand in a revolving door as he tried to push his way in, and the mood turned angry, with some activists pounding on the lobby windows. Some supporters tried to join the demon- 
stration from within the hotel, but were prevented from exiting by security. Unable to get inside, the demonstrators eventually dispersed, leaving behind a wet stack of real and satirical reports as testament to the failure of research and policy to meaningfully alter the conditions causing homelessness.

Scenes like this one have become familiar in urban Canada: a direct action by impoverished, racialized, Indigenous, disabled, homeless, psychiatrized, and otherwise stigmatized protestors and their allies, targeting a site of political and economic injustice, forcibly contained and dispersed by police.

What sets this demonstration apart, though, is the event whose opening reception the protestors aimed to disrupt: the 2014 National Conference on Ending Homelessness.

How do we account for the apparent contradiction of an anti-poverty protest targeting a conference to end homelessness? What can be learned from this familiar yet surreal scene-poor and homeless protestors locked outside a conference in the rain while delegates enjoy wine and salmon skewers inside-and what are its implications for both groups' stated goal of ending homelessness?

To explore these questions, this paper will locate this event within its larger context, examining the dilemmas it raises about inclusion for people facing homelessness. Drawing upon my own participation in and observation of these events, I will discuss the significance of Canada's national conferences on homelessness: as discursive sites in which framings of homelessness are defined, circulated and consolidated; as sites of governance, in which policy-makers and non-government actors develop policy and program responses; and as sites of contestation, in which people facing homelessness claim space for oppositional perspectives.

Arguing that neoliberal hegemony "is sustained not only through (external) force but also by processes of identification and responsibilization," Mayer and Kunkel $(2012$, p. 6) call for studies that combine post-structuralist and political-economic approaches, to examine what Brenner and Theordore have termed "actually-existing neoliberalisms" (cited in Mayer \& Kunkel, 2012, p. 3). This paper, accordingly, examines the discourses, practices of governance, and contestations enacted through conferences on homelessness, while attending to the ways in which these may hold in place or unsettle the structural, material conditions that give rise to homelessness. In so doing, it contends that the norms of professionalism and the tactics of collaborative governance that characterize these conferences risk leaving unchallenged the fundamental causes of homelessness, and that "outsider" interventions by people facing homelessness offer a necessary corrective to these tendencies.

In order to situate these arguments, the paper first introduces the larger context of homelessness in Canada, demonstrating that it is produced by, and embedded in, current economic, political, social, and institutional arrangements. It then briefly surveys three kinds of responses to homelessness in Canada-grassroots activism, advocacy, and service provision-examining their understanding of homelessness, their activities and tactics, and the role of people facing homelessness within them. Turning to national conferences on homelessness, the paper considers their significance as sites of homelessness governance, and examines to what extent these influential gatherings challenge the arrangements through which homelessness is produced. Finally, the paper introduces a national council of persons with lived experience of homelessness. This council's interventions call upon organizations in the homelessness sector to engage the leadership of people facing homelessness in all initiatives to end it.

\section{Context: Homelessness in Canada}

To fully understand these events and their significance, it is first necessary to step back and consider the current state of homelessness in Canada, the economic and policy drivers that produce it, and the relations of exclusion and disenfranchisement that characterize it.

\subsection{State of Homelessness in Canada}

While not as rampant as in the US, homelessness in Canada is a large and growing problem affecting men, women, youth, and families with children. It is found in major urban centres, small cities, rural areas and the North. Homelessness statistics have not been systematically tracked at the national level by government; however, a recent comprehensive analysis estimates that 235,000 people in Canada experience homelessness every year, 35,000 on any given night (Gaetz, Gulliver, \& Richter, 2014). ${ }^{1}$

Many others are currently housed but at imminent risk of homelessness due to factors including family violence and severely unaffordable housing. In Canada's largest cities, about one in five renter households have low incomes and pay more than half their income on housing costs, leaving them vulnerable to homelessness (Gaetz et al., 2014, p. 43). In Toronto, for example, a recent survey of more than 1,500 renter families in lowincome neighbourhoods found that $32 \%$ were paying more than half their income on rent; one in three were at risk of homelessness due to combined problems with unaffordability, overcrowding, poor unit and building conditions, safety concerns, and risk of eviction (Paradis, Wilson, \& Logan, 2014).

Certain groups are disproportionately represented among those facing homelessness in Canada. These include Indigenous people; people with physical and mental health disabilities and addictions; youth; and sur-

\footnotetext{
${ }_{1}^{1}$ This includes persons without a stable home of their own, who are staying in shelters $(180,000)$, unsheltered $(5,000)$, or provisionally accommodated in institutions, with other households, or in other temporary dwellings such as motels $(50,000)$.
} 
vivors of violence. Families with children are the fastestgrowing group experiencing homelessness (GulliverGarcia, 2016) and the share of older adults is increasing rapidly in some urban centres (City of Toronto, 2013). Specific groups are also over-represented among subgroups of the homeless population: for example, LGBTTQ2 $S^{2}$ youth make up a large proportion of homeless youth (Abramovich, 2014); and among families using homeless shelters, lone-mother led families, young mothers, those with infants, Black and Indigenous families, and those with precarious immigration status are over-represented (Paradis, Novac, Sarty, \& Hulchanski, 2008). Refugees and recent immigrants face high rates of inadequate housing and hidden homelessness (Murdie \& Logan, 2010; Preston, Murdie, D’Addario, Sibanda, \& Murnaghan, 2011).

\subsection{Economic and Policy Drivers of Homelessness}

Homelessness has emerged as a mass phenomenon in Canada only in the past three decades; indeed, before the 1980s, the word "homeless" barely entered the public lexicon, and when it did, it referred to single adult men who lived in rooming houses and hotels rather than in a family home (Hulchanski, Campsie, Chau, Hwang, \& Paradis, 2009).

As is the case in other rich countries of the global North, the emergence of mass homelessness in Canada parallels the economic and policy shifts characteristic of neoliberal globalization: the deregulation of markets and the increasing flow of capital and labour across national borders, accompanied by the constriction of state social spending and the prioritizing of deficit reduction in economic policy. These trends enable enormous concentration and privatization of wealth, resulting in high levels of inequality and polarization in cities (Walks, 2013). The United Nations Special Rapporteur on the right to adequate housing has identified these trends as a key structural cause of homelessness (United Nations General Assembly, 2015, para. 28 and 31).

These global trends undergird the direct structural drivers of homelessness in Canada. Primary among these is colonization, which includes three key elements directly tied to homelessness. First, ongoing contravention of treaties, environmental devastation of Indigenous territories for resource extraction, and deep disparities in state social spending, systematically impoverish First Nations and Northern communities and Aboriginal people living in urban centres (Patrick, 2014). Secondly, the legacy of dispossession, displacement, child abduction, and genocidal social violence has given rise to intergenerational trauma that ruptures families and communities, and heightens vulnerability to violence, addiction, and mental health problems (Menzies, 2009; Patrick, 2014). Finally, racism against Indigenous people pervades service systems such as health care and child welfare (Allan \& Smylie, 2016); produces widespread discrimination in housing and employment; and incites horrifying levels of violence, in particular towards Indigenous women.

A second key economic and policy driver of homelessness is income insecurity. Labour market trendsincluding the decline of manufacturing and organized labour, the shift to a polarized knowledge and service-based economy, and the increase in precarious employment-have produced an economy in which an increasing proportion of workers have precarious jobs (PEPSO Research Alliance, 2012) and women and racialized groups are concentrated in the lowest-paying sectors (Block \& Galabuzi, 2011). Meanwhile, the restriction of state income support programs and other services has deepened the poverty of people excluded from the labour market, including those who are unemployed, injured workers, people with disabilities and lone mothers. Social assistance rates, for example, are far below the poverty line in every province and territory (Tweddle, Battle, \& Torjman, 2015). At the same time, changes to immigration policy have enabled industry's increasing reliance on temporary workers (Sharma, 2006), and produced protracted periods of precarious status for those settling in Canada, leading to deep and long-lasting income disparities between Canadian-born workers and those born elsewhere (Goldring \& Landolt, 2012).

And finally, the changing economic and policy landscape of housing drives much of the increase in homelessness in Canada. After decades of robust housing production spurred by both state-led social housing programs and government subsidies to private rental housing development, the federal and provincial orders of government largely withdrew from housing provision in the 1990s (Suttor, 2015). As a result, during a period in which Canada's population has increased by $30 \%$, the annual national investment in housing has decreased by $46 \%$ (Gaetz et al., 2014). In Canada, as in many other rich countries, the housing system has become increasingly market-based, with real estate development and speculation driving urban economies (Picture the Homeless, 2012) and housing treated as a commodity rather than a social right (United Nations General Assembly, 2015, para. 29).

\subsection{Market-Based Citizenship and Social Exclusion}

The demographic profile of homelessness and risk of homelessness in Canada is composed of those most disadvantaged and excluded by the prevailing market logic of neoliberalism. While the material causes and effects of this exclusion are devastating to health and life, scholars have long insisted that the social dimension of homelessness also demands attention. Kennett (1999) links homelessness in the UK to a shift from a Keynesian model of social citizenship in which all are guaranteed a basic standard of living, to a market-based model in which social entitlements are contingent on market participation. Social rights scholar Bruce Porter (2007) notes that

\footnotetext{
${ }^{2}$ Lesbian, gay, bisexual, transsexual, transgender, queer, and two-spirited.
} 
in Canada, the exclusion of social and economic rights from protection by the courts amounts to a denial of poor and homeless people's citizenship and even their status as persons under Canada's Charter of Rights. And Liggett (1991, p. 205), following Patterson's work on slavery, argues that people who are homeless are consigned to a radical denial of personhood she refers to as a "social death." People who are poor and homeless are targeted with interpersonal and institutional stereotyping and stigma. In popular depictions and policy discourses, they are portrayed as dishonest and blameworthy, as silent and passive victims, or as incompetent and disordered (Rosenthal, 2000; Swanson, 2001). The exclusion homeless people face is not only social; it is given legal force through the regulation and criminalization of their activities of daily survival through municipal and provincial laws (Baillargeau, 2014; Hermer \& Mosher, 2002; O'Grady, Gaetz, \& Buccieri, 2011).

Theorists are not the only ones who note the importance of the social dimension of homelessness. People facing homelessness, too, often emphasize that dehumanization and the denial of fundamental rights are among the most devastating aspects of their experience (United Nations General Assembly, 2015, para. 22). This was the case in my own participatory research with women facing homelessness (Paradis, 2014): participants' individual and political claims focused on selfdetermination and personhood even more prominently than the material necessities of life.

\section{Insiders and Outsiders: Responses to Homelessness in Canada}

As shown above, homelessness in Canada is actively produced by economic, political, social and institutional arrangements. Responses to homelessness in Canadaincluding grassroots activism, advocacy, and servisse and policy responses-differ in the extent to which they challenge or hold in place these arrangements. As suggested by the example of the Vancouver protest and conference, these responses also differ in their understanding of homelessness, their activities and tactics, and the role of people facing homelessness within them. While responses fall generally into these three categories, it should be noted that individuals and organizations may be engaged in more than one type of response. Indeed, some significant initiatives have involved coalitions across activist, advocacy, and service-oriented groups.

\subsection{Grassroots Activism}

Grassroots activist responses to homelessness have mainly been led by local anti-poverty groups such as the Carnegie Community Action Project (one of the organizers of the protest) and Ontario Coalition Against Poverty. Their leadership and membership is largely composed of people facing poverty, homelessness, and disability, along with some non-poor allies. Grassroots groups of- ten embrace a radical and intersectional analysis, including a critique of capitalism, a rejection of institutional responses, and a naming of social relations of power and dominance-such as colonization, racism, sexism, poorbashing, and exclusion of people with disabilities - as key forces in producing homelessness and poverty. They often take a direct action approach, and their campaigns tend to be reactive to local events, such as shelter closures, welfare cuts, gentrification, and displacement. Tactics include squatting, encampments, and occupations, such as the Oppenheimer Park encampment in Vancouver that had recently been dispersed at the time of the protest, and the Super InTent City encampment in Victoria. These interventions not only directly claim homespaces for people facing homelessness, they also propose a prefigurative vision of an autonomous community outside colonial, capitalist, and institutional relations.

\subsection{Advocacy}

Advocacy responses, on the other hand, have generally been initiated by formal organizations such as legal clinics. Campaigns often focus on the lack of state measures to effectively address homelessness, using the Canadian courts (Heffernan, Faraday, \& Rosenthal, 2015), international human rights forums (Monsebraaten, 2016), public awareness campaigns (YWCA Canada, 2013a), and lobbying of elected officials to urge policy and program changes. Direct involvement of people facing homelessness in such campaigns has been variable, with some planned and led by professional advocates while others are shaped by coalitions of formal organizations and grassroots groups (Dirks, 2015). Advocacy on homelessness in Canada has often adopted a social justice or rights-based framing, in which homelessness is identified as a violation of human rights. While the role of inequities based on race, gender, and disability is often acknowledged, fundamental critiques of capitalism and institutionalization are typically absent, and state-led solutions are promoted. One major focus of these campaigns, for example, has been to urge the federal government to implement a national housing strategy.

\subsection{Service and Policy Responses}

Service and policy responses to homelessness, meanwhile, have tended to focus on providing material supports to people facing homelessness, and less so on addressing its root causes or its social dimensions. The uneven emergence of homelessness in Canada, along with jurisdictional confusion about responsibility for it, produced a fragmented collection of front-line services across the country. These include charitable, faith-based, and community-based organizations large and small, municipal services, and homeless-serving programs within larger health and social service institutions. These are funded through private donations and a patchwork of municipal, provincial and federal programs to provide 
critically needed shelter, food, medical care and other supports to people who would otherwise lack access to the bare necessities of life. From time to time, people who are poor and homeless may be consulted in policy development or hired in "peer" roles to provide services; but typically, service and policy responses confine people facing homelessness to a passive role as objects of policy-making and recipients of services.

In 2007 the federal government introduced the Homelessness Partnership Secretariat-now Homelessness Partnering Strategy (HPS) - to provide direct support to homelessness services via local entities in designated communities $^{3}$ across Canada. Through its requirement for local service coordination and its regulation of the activities for which funds could be used ${ }^{4}$, HPS has shaped the sector's understanding of and response to homelessness. Coordination of the sector increased further as a result of the founding of the Canadian Alliance to End Homelessness (CAEH) in 2013, a national coalition of services whose aim is to promote the development and implementation of local and provincial ten-year plans to end homelessness ${ }^{5}$. While individual homelessness service organizations have wide variations in history, mission, philosophy and activities, the influence of HPS and CAEH has contributed to a technical and service-oriented approach to homelessness across the sector as a whole.

\subsection{Insiders and Outsiders}

One key difference among responses to homelessness is their adoption of an insider or outsider stance-that is, the extent to which their discourses, activities, and demands align with or are contrary to those of the powerful entities they seek to influence. In her study of homelessness sector organizations in Chicago, Mosley (2012) found that organizations reliant on service contracts and funding from government sources tend to engage in advocacy using insider tactics such as participation in sectoral networks and meeting with policy-makers. Moreover, their advocacy goals typically focus on heightening the visibility of their organizations, forming reciprocal relationships with funders, promoting policy and program directions that align with their funded services, and brokering resources. In contrast, organizations reliant on private funding focus their advocacy efforts on raising awareness among their donors and the general public; when they do participate in discussions with policymakers, they see themselves as providing information to inform policy decisions. Both groups explicitly reject confrontational approaches, instead seeking to position themselves as partners in the planning and delivery of policies and programs, or as outside experts.
Neoliberal political and institutional trends have produced a shift from government-characterized by the centralized development and delivery of policy through vertical structures-to governance-characterized by horizontal policy networks in which non-government organizations play an active role. The trouble is, Mosley explains, as participants in collaborative governance, "advocacy by nonprofit service providers may serve to amplify rather than challenge current political and institutional arrangements" (2012, p. 21). If, as suggested above, homelessness is a direct result of these economic, political and institutional arrangements, advocacy of this kind risks leaving unchallenged the fundamental causes of homelessness.

A further concern arises with what Mosley (p. 5) identifies as processes of "isomorphism"-that is, the tendency to adopt specific practices and discourses in order to be understood as legitimate. In fostering reciprocal, collaborative relationships with government, organizations tend to conform to institutional and professional norms in their language and tactics. She notes that organizations that fail to conform to these norms in communication with governments-such as those engaging in activities such as protest-tend to be isolated outsiders in networks of governance, lacking influence and connections. In other words, organizational environments shaped by isomorphism produce outsiders whose communications are devalued.

\section{Conferences as Sites of Governance and Contestation}

\subsection{National Homelessness Conferences in Canada}

With increasing coordination of the homelessness sector in Canada, conferences have become key sites of these dynamics. The 2014 Vancouver conference, along with previous national conferences held in Calgary (2009), Montréal (2010), and Ottawa (2013), brought together academics, service managers and policy makers for agendas focused on presentations of scholarly research, demonstration studies, and policy options. Elected officials from all levels of government-including those whose policy portfolios perpetuate the very conditions that produce homelessness-were strategically included as plenary speakers, and received with polite applause. Critical discourses and confrontational tactics were largely absent; instead, the proceedings emphasized collaboration, evidence-sharing and consensusbuilding around favoured intervention approaches.

Also largely absent from the 2009, 2010 and 2013 conferences were people facing homelessness and

\footnotetext{
3 "Designated communities" are municipalities or regions considered to have a significant problem with homelessness. There are currently 61 such entities across Canada.

${ }^{4}$ For example, local entities are prohibited from using HPS funds to develop or repair social housing.

5 According to its website, CAEH was formed "to create a national movement to end homelessness in Canada from the community up" through four key activities: raising awareness of homelessness; encouraging governments and communities to commit to ending homelessness through the implementation of ten year plans; providing information and tools to communities to enable the development of such plans; and pursuing provincial and federal policy change (http://www.caeh.ca/about-caeh).
} 
the grassroots self-advocacy organizations representing them. These gatherings hosted hundreds of attendees and offered dozens of workshops, but few were from the perspective of lived experience. A handful of people facing homelessness and anti-poverty activists were present as delegates, but there was no space in which to connect with each other and formulate demands to bring to the conference as a whole. Overall, at these gatherings, people facing homelessness were talked about, not with, and for the most part this talk lacked the urgency of direct engagement with a life-threatening catastrophe. Many of the academics, policy makers, and service providers in attendance were staunch anti-homelessness advocates, but our discussions took place in the absence of an organized, visible collectivity of people living in poverty to challenge our analyses and investments. Processes of isomorphism shaped these spaces, producing a normative culture of middle-class professionalism which further discouraged expressions of outsider perspectives and identities ${ }^{6}$.

\subsection{Conferences as Sites of Governance: The Example of Housing First}

The prevailing discourse at these conferences tended to construct homelessness as a technical problem to be remedied with targeted service and policy interventions to be delivered by professionals, rather than as a problem of economic and social injustice requiring structural change. This discursive framing is exemplified in the sectoral embrace of Housing First, leading to its implementation as federal policy in 2014. ${ }^{7}$

Housing First was first implemented as policy in Canada by the province of Alberta, drawing heavily upon a US model that emphasized the cost-recovery potential of targeting housing and supports to a small group, defined as chronically homeless, who are understood to consume a disproportionate share of shelter nights and costly emergency services. ${ }^{8}$ A federally-funded, multiyear demonstration study on Housing First, called At Home / Chez Soi, was launched in 2009 in five Canadian cities. Its methodology, preliminary results, and findings were prominently featured at the 2009, 2010, 2013 and 2014 national conferences. The Canadian Alliance to End Homelessness, with the support of a research consortium called Canadian Observatory on Homelessness, strongly promotes Housing First as an evidence-based service and policy approach, and the national conferences co-hosted by COH and CAEH in 2013 and 2014 have been key sites in advocacy for its adoption by the federal government. The federal Homelessness Partnering Strategy directives for implementation of the program are highly technical, requiring communities to conduct local homeless counts using a consistent methodology, assess eligibility for Housing First programs employing a prescribed vulnerability assessment tool, and collect and report outcome data (Government of Canada, 2014). The 2013 and 2014 conferences have included concurrent session "streams" dedicated to disseminating the tools and techniques of Housing First implementation.

Critics have raised multiple concerns about the federal Housing First policy. They suggest that it excludes women, families, and others whose experiences don't align with the definition of "chronic homelessness" (YWCA Canada, 2013b); that its effectiveness is limited by the shortage of social housing and affordable, goodquality units in the private rental market (Stock, 2016); and that it falsely promises to "end homelessness" while failing to address root causes such as poverty and lack of affordable housing (Heffernan, Todorow, \& Luu, 2015).

Katz, Zerger and Hwang (2016, p. 1), while acknowledging these critiques of the Housing First program, also point to broader problems with what they refer to as the Housing First "conversation" - that is, the marketing of Housing First as a solution to homelessness by policymakers, researchers, and service managers. They suggest that the sectoral conversation about Housing First has muted necessary discussion of the structural drivers of homelessness, that it has framed homelessness as an individual affliction requiring a technical cure, and that it reifies market logics of scarcity, competition, and costrecovery. In so doing, they suggest, the Housing First conversation may in fact undermine the ultimate goal of ending homelessness in Canada.

\subsection{Outsiders Storming In: Claiming Discursive Space}

The Vancouver protest sought to interrupt this conversation, and draw attention to the damaging effects of its limited scope. The call-out for the protest, circulated on Facebook ${ }^{9}$, condemned the medical and police control of poor and Indigenous people's lives and bodies via

\footnotetext{
${ }^{6}$ The All Our Sisters national conferences on women and homelessness in London, Ontario in 2011 and 2014 (http://www.alloursisters.ca) have offered an alternative model, grounded in feminist praxis. Both conferences included a large proportion of delegates facing homelessness-about one in four attendees-whose registration fees and travel costs were covered by the conference. Workshops and plenary sessions included a balance of expertise from research, services, activism, and lived experience. There was a room set aside for delegates facing homelessness to connect with each other and take a break from the sometimes-alienating conference culture. In 2014, the conference was co-chaired by a group of women facing homelessness, and even included a demonstration that was organized from within the conference.

${ }^{7}$ As defined by HPS, Housing First programs provide permanent housing with supports to persons who are considered to be chronically homeless and have "disabling conditions" such as mental health problems and addictions (Government of Canada, 2014).

${ }^{8}$ Though the right-leaning governments that adopted Housing First as policy in the US and Alberta (and later as federal policy in Canada) emphasized its cost-recovery potential, it is important to note that many scholars, practitioners and advocates consider it to be a "rights-based intervention" (Gaetz, Scott, \& Gulliver, 2013, p. 2). Two of the programs in which the model originated-Pathways to Housing in New York City and Houslink in Torontoemerged out of the mental health consumer-survivor movement and were founded on the principles of consumers' right to housing, and their right to choose whether or not to engage in treatment (Waegemakers Schiff \& Rook, 2012).

${ }^{9}$ https://www.facebook.com/events/1493810717546493/?active_tab=highlights
} 
state and institutional responses to homelessness. The "elite class of managers" attending the conference was complicit in this régime of control, the online flyer declared. It concluded: "The Social Housing Alliance calls for a major mobilization to confront, expose, and oppose the government policies and NGO industries that manage homeless, low-income, and Indigenous people without challenging or disrupting the systems and social conditions that cause homelessness and poverty." The locked doors and police barricade marked this message, and the people who delivered it, as unwelcome and dangerous. The conference organizers and attendees, meanwhile, shielded from the protest by police, were implicitly positioned in alignment with exclusionary responses to homelessness driven by what Baillargeau (2014) has identified as a rationality of public order.

This action had a significant historical resonance with the fifth International Conference on AIDS in Montréal in 1989, at which 300 AIDS activists stormed in uninvited and seized the microphone at the opening plenary to open the conference on behalf of people with AIDS, receiving a standing ovation even from many of the scientists present (McCaskell, 2011). That demonstration and the changes that followed it radically altered research and practice on HIV/AIDS. In claiming their place at the table, the protestors ushered in a new era in which people with AIDS and the organizations that represent them are included in framing policies and programs, defining research priorities and ethics, and providing services. The inclusion, leadership, and unique perspectives of those directly affected have been critical to global progress in this sector, and have influenced other sectors as well. Nevertheless, decades later, AIDS conferences continue to be sites of contestation at which activists underline the social dimensions of an epidemic that is still often viewed only as a technical, scientific challenge. As Tim McCaskell (2012), a leader of the 1989 action and lifelong activist, notes about the 2012 International AIDS Conference, "If many of the key issues about AIDS have now shifted from the medical to the social, activism represents the political muscle to actually demand implementation".

Like homeless encampments in public parks and squares, these actions have multiple objectives and effects. First, they claim space for the embodied presence of stigmatized groups who are physically and/or socially excluded from the places in question. Secondly, they make unsanctioned use of these spaces, engaging in talk and activities that fall outside the legitimate or prescribed conduct for these social settings. Thirdly, they serve as a reminder of realities that may be obscured in (or by) these sites: just as an encampment reminds passersby that homelessness persists in their prosperous city, these actions seek to remind conference attendees of the deeper social and structural dimensions of AIDS and homelessness, and of the suffering they inflict on so many. Fourthly, in so doing, they summon not only the attention of witnesses, but their self-reflection-an accounting for their own positions in relation to homelessness and AIDS, and their role in perpetuating or eliminating these forms of social violence. Fifth, they give collective voice to a demand for change. And finally, as McCaskell suggests, they apply pressure to powerful entities, with a goal of changing prevailing economic, political, social and institutional arrangements.

Canadian social rights scholar Bruce Porter (2007) examines failed litigation for economic and social rights, and asks whether there is value in persisting with these unsuccessful attempts. He concludes that whether they succeed or fail, the importance of these cases lies in their potential to give voice to the aspirations, perspectives, and claims of individuals and communities who have been excluded from mainstream conceptions of rights and citizenship. In "claiming adjudicative space" (p. 77) for these excluded perspectives and entering them into the record, he suggests, such cases assert the personhood and citizenship of the claimants, and contribute to incremental shifts in law that can lead to important interpretive changes down the road. I contend that actions like the Vancouver protest have a similar effect: they claim discursive space for identities, points of view, modes of expression, social critiques, and demands that have been excluded by the norms of professionalism and tactics of collaborative governance that shape national conferences on homelessness.

\section{Outsiders within: Nothing About Us, Without Us}

\subsection{The Formation of the Lived Experience Advisory Council}

If one goal of such action is to confront witnesses with a painful reality and incite them to examine their own positions in relation to it, the Vancouver protest at first glance appears to fail in that regard. Instead of inspiring a reconsideration of relationships that could lead to new possibilities and alliances, it seemed to simply re-enact and entrench relations of power and dominance: poor and homeless people were shut out, wet, cold, disregarded, injured, and policed; while conference delegates stayed inside, warm and well-fed, their comfort protected, at a comfortable distance above the fray.

But while the optics of the protest suggested an unbreachable divide between conference attendees and protestors, the reality was much more complex. The physical spaces and political alignments inhabited by the two sides were more porous than it appeared. Many conference delegates managed to find a way outside to join the protest. A conference delegate who uses a wheelchair convinced the security guards to let her back in to the hotel, with an organizer of the protest posing as her attendant. With the help of other conference delegates, the protestor successfully negotiated with the conference organizers to allow her to address the reception.

Perhaps most significantly, many of the conference delegates who acted in solidarity with the protest were 
themselves facing homelessness and poverty (Jarrett, 2016). For the 2014 conference, the Canadian Alliance to End Homelessness and Canadian Observatory on Homelessness sponsored the attendance of more than forty delegates with lived experience, including some local activists who had also helped organize the protest. Two workshops at the conference focused on inclusion, several others featured presenters with lived experience, and a meeting room was made available for people facing homelessness to re-charge and collaborate. These initiatives not only opened a space for the perspectives and claims of delegates facing homelessness, they also made room for professional delegates to verbalize oppositional viewpoints and explore new alliances.

Delegates facing homelessness and their allies seized these opportunities. One group developed a declaration of principles for inclusion of people with lived experience, while a second brought forward ideas for connecting with local activist groups at future conferences. The declaration of principles-under the banner of the disability rights slogan "Nothing About Us, Without Us"was presented by lived experience delegates during the conference's final plenary lunch.

Out of these collaborations, the Lived Experience Advisory Council (LEAC) emerged. This group includes lived experience leaders from across Canada, along with professional allies (including this author). Members represent a broad diversity of social locations, political inclinations, and lived experiences with homelessness and poverty. Members also bring different backgrounds with insider and outsider tactics: some have been involved in encampments and other direct actions, some in human rights advocacy, some in service provision, and some in mechanisms of collaborative governance such as municipal committees. Many have been involved in multiple types of responses.

The group stayed in contact after the 2014 conference, using email and the occasional borrowed teleconference line to articulate a mission, develop recommendations on inclusion for the conference organizers, and plan session proposals for the following year. It has negotiated many of the challenges that face poor people's movements, including the catch-22 of finding resources to support its work while maintaining its autonomy. Precarious housing, unstable and inadequate incomes, discrimination and violence continue to take a toll on members' health and well-being, and sometimes make it impossible to participate.

But in the face of these challenges, LEAC has intervened in the processes of isomorphism that shaped previous national conferences, holding open a space for new kinds of conversations about homelessness. One of three sessions led by LEAC at the 2015 national conference, for example, was an activist-ally dialogue in which the panelists began by moving the furniture, breaking apart the rows of chairs facing a head table and rearranging them into a huge circle. The message was clear and concrete: ending homelessness will require new approaches that challenge existing relations of power and dominance based on class, race, gender, ability, age and social condition.

\subsection{Tools for Inclusion}

Out of dialogues held at 2014 and 2015 conferences, LEAC developed two tools for the promotion of leadership and inclusion: a statement of principles, and a checklist for organizing inclusive events. These documents are at once pragmatic and visionary, calling upon organizations in the homelessness sector to engage in new relationships with people facing homelessness ${ }^{10}$.

The preamble to the statement of principles reads:

"We believe that without including individuals with lived experience in the decision making process, in research, and in all other endeavours, it creates an unbalanced approach to ending homelessness in Canada.

\section{$[\ldots]$}

These principles point to the importance of first voice inclusion in all endeavours to end homelessness. This is true of any social issue - the people who are living it usually have the best understanding about what the problem is and what needs to be done to address it. Inclusion is especially vital in the context of homelessness, though, because being excluded and silenced is a huge part of the experience of homelessness and poverty. The belief that people who are homeless do not have the competence to participate as equals in organizations is layered on top of the other stereotypes directed at us because of racism, sexism, ableism, poor-bashing, and other oppressions.

Many organizations are learning to value lived expertise, but overcoming outdated, paternalistic beliefs and practices doesn't happen overnight. Service providers, researchers and policy-makers need to work alongside people with lived experience to create new structures in which we come together as equals. We hope this document can provide support to professionals and people with lived experience as we all work together to plan and implement these changes."

The document underlines the importance of including people with lived experience as equals at all levels of the organization, and in all activities and decisions, and it provides practical guidelines for how to accomplish this objective.

\section{Conclusion}

With the neoliberal shift to horizontal, distributed policymaking, homelessness conferences in Canada have

\footnotetext{
$\overline{10}$ These tools can be viewed on the Homeless Hub website at http://www.homelesshub.ca/NothingAboutUsWithoutUs
} 
emerged as important sites of governance in which formal homelessness sector organizations collaborate with state actors in the development and delivery of homelessness policies. There is evidence, though, that the advocacy activities of such organizations tend to focus on maintaining relationships and securing funding streams. As a result, sectoral conversations about policies such as Housing First risk leaving unchallenged the root causes of homelessness. Meanwhile, processes of isomorphism at these conferences produce a normative culture in which the language, actions, priorities, and self-presentation of activists and persons facing homelessness are marked as deviant and therefore illegitimate, thereby perpetuating the relations of exclusion, disenfranchisement, and dehumanization that are themselves key elements of homelessness.

Poor and homeless activists and their allies have contested these tendencies from both outside and inside conferences. Their interventions have claimed space for the bodies, perspectives, modes of expression, and demands of individuals and collectivities who have faced exclusion, invisibility and stigma in normative conference settings-and in Canadian society at large. In so doing, they contest the ways in which conferences themselves risk becoming conscripted into a neoliberal project to "facilitate the spread of market rule into more and more arenas of social life" (Mayer \& Kunkel, 2012, p. 11)-both through their role in neoliberal policy transfer, and their reproduction of neoliberal subjectivities.

The interventions of homeless activists from outside and within these conferences make clear that the goal is not simply for homeless and poor people to be included in the normal operations of organizations and conferences. Instead, the active participation and leadership of people facing homelessness calls into question these operations, and the prevailing social, political, economic and institutional arrangements of which they are a part. The outsider perspectives, demands, and tactics that emerge from lived experience are necessary for the transformation of the structures and relations that produce homelessness. It would be impossible to end homelessness without them.

\section{Acknowledgments}

The author wishes to acknowledge the members of the Lived Experience Advisory Council for conversations that contributed to the development of the ideas presented here.

\section{Conflict of Interest}

The author declares no conflict of interests.

\section{References}

Abramovich, I. A. (2014, June 23). Solutions: LGBTQ youth homelessness. Homeless Hub Research Mat- ters. Retrieved from http://homelesshub.ca/blog/ solutions-lgbtq2-youth-homelessness

Allan, B., \& Smylie, J. (2015). First peoples, second-class treatment: The role of racism in the health and well-being of Indigenous peoples in Canada. Toronto: Wellesley Institute.

Baillargeau, E. (2014). Governing public nuisance: Collaboration and conflict regarding the presence of homeless people in public spaces of Montreal. Critical Social Policy, 354-373.

Block, S., \& Galabuzi, G.-E. (2011). Canada's colourcoded labour market: The gap for racialized workers. Toronto: Wellesley Institute and Canadian Centre for Policy Alternatives.

City of Toronto. (2013). 2013 Street needs assessment results. Toronto: City of Toronto.

Dirks, Y. (2015). Community campaigns for the right to housing: Lessons from the $\mathrm{R} 2 \mathrm{H}$ coalition in Ontario. Journal of Law and Social Policy, 24, 135-142.

Gaetz, S., Gulliver, T., \& Richter, T. (2014). The state of homelessness in Canada 2014 (Homeless Hub paper \#5). Toronto: The Homeless Hub Press.

Gaetz, S., Scott, F., \& Gulliver, T. (2013). Housing First in Canada: Supporting communities to end homelessness. Toronto: Canadian Homelessness Research Network Press.

Goldring, L., \& Landolt, P. (2012). The impact of precarious legal status on immigrants' economic outcomes (IRPP Study No. 35). Montréal: Institute for Research on Public Policy.

Government of Canada. (2014). Homelessness partnering strategy directives. Ottawa: Employment and Social Development Canada. Retrieved from http:// www.esdc.gc.ca/eng/communities/homelessness/ funding/directives.shtml\#d15

Gulliver-Garcia, T. (2016). Putting an end to child and family homelessness in Canada. Toronto: Raising the Roof. Retrieved from http://www.raisingthe roof.org/wp-content/uploads/2015/10/CF-ReportFinal.pdf

Heffernan, T., Faraday, F., \& Rosenthal, P. (2015). Fighting for the right to housing in Canada. Journal of Law and Social Policy, 24, 10-45.

Heffernan, T., Todorow, M. \& Luu, H. (2015, July 7). Why Housing First won't end homelessness. Rabble. Retrieved from http://rabble.ca/blogs/bloggers/viewsexpressed/2015/07/why-housing-first-wont-end-ho melessness

Hermer, J., \& Mosher, J. (2002). Introduction. In J. Hermer \& J. Mosher (Eds.), Disorderly people: Law and the politics of exclusion in Ontario (pp. 11-21). Halifax: Fernwood Publishing.

Hulchanski, J. D., Campsie, P., Chau, S., Hwang, S., \& Paradis, E. (2009). Homelessness: What's in a word? In J. D. Hulchanski, P. Campsie, S. Chau, S. Hwang \& E. Paradis (Eds.), Finding home: Policy options for addressing homelessness in Canada. Toronto: Canadian Homelessness Research Network. Retrieved from 
http://homelesshub.ca/resource/homelessness-wh at\%E2\%80\%99s-word

Jarrett, H. (2016). Nothing about us without us: Lived experience leaders from across the country call for inclusion in the design of Canada's National Housing Strategy. Homeless Hub. Retrieved from http://homelesshub.ca/blog/nothing-about-us-with out-us-lived-experience-leaders-across-country-callinclusion-design

Katz, A., Zerger, S., \& Hwang, S. (2016). Housing First the conversation: Discourse, policy and the limits of the possible. Critical Public Health, 1-9. doi:10.1080/09581596.2016.1167838

Kennett, P. (1999). Homelessness, citizenship, and social exclusion. In P. Kennett \& A. Marsh (Eds.), Homelessness: Exploring the new terrain (pp. 37-60). Bristol: The Policy Press.

Liggett, H. (1991). Where they don't have to take you in: The representation of homelessness in public policy. Journal of Planning Education and Research, 10(3), 201-208.

Mayer, M., \& Kunkel, J. (2012). Introduction. In J. Kunkel \& M. Mayer (Eds.), Neoliberal urbanism and its contestations: Crossing theoretical boundaries (pp. 326). London: Palgrave Macmillan.

McCaskell, T. (2011). Taking our place. The Positive Side, summer 2011. Retrieved May 2016 from http://www.catie.ca/en/positiveside/summer-2011/ taking-our-place

McCaskell, T. (2012, July 29). What an AIDS conference should look like: Taking stock following the $19^{\text {th }}$ international AIDS conference in Washington D.C. Daily Xtra. Retrieved May 2016 from http:// www.dailyxtra.com/canada/news-and-ideas/news/ aids-conference-look-like-51241?

Menzies, P. (2009). Homeless Aboriginal men: Effects of intergenerational trauma. In J. D. Hulchanski, P. Campsie, S. Chau, S. Hwang \& E. Paradis (Eds.), Finding home: Policy options for addressing homelessness in Canada. Toronto: Canadian Homelessness Research Network. Retrieved from http:// homelesshub.ca/sites/default/files/6.2\%20Menzies \%20-\%20Homeless\%20Aboriginal\%20Men.pdf

Monsebraaten, L. (2016, February 20). Advocates taking Canada's housing policy to UN. Toronto Star. Retrieved from https://www.thestar.com/news/gta/ 2016/02/20/advocates-taking-canadas-housing-poli cy-to-un.html

Mosley, J. (2012). Keeping the lights on: How government funding concerns drive the advocacy agendas of nonprofit homeless service providers. Journal of Public Administration Research and Theory, 22(4), 841-866.

Murdie, R., \& Logan, J. (2010). Precarious housing and hidden homelessness among refugees, asylum seekers, and immigrants: Bibliography and review of Canadian literature from 2005 to 2010. Toronto: CERIS-The Ontario Metropolis Centre.
O'Grady, B., Gaetz, S., \& Buccieri, K. (2011). Can I see your ID? The policing of youth homelessness in Toronto. Toronto: Street Youth Legal Services.

Paradis, E. (2014). "I would like us to unite and fight for our rights together because we haven't been able to do it alone": Women's homelessness, disenfranchisement, and self-determination. In J. Kilty (Ed.), Within the confines: Women and the Law in Canada. Toronto: Women's Press/CSPI.

Paradis, E., Novac, S., Sarty, M., \& Hulchanski, J. D. (2008). Better off in a shelter? A year of homelessness and housing among status immigrant, non-status migrant, and Canadian-born families (Research Paper 213). Toronto: University of Toronto Cities Centre.

Paradis, E., Wilson, R., \& Logan, J. (2014). Nowhere else to go: Inadequate housing and risk of homelessness among families in Toronto's aging rental buildings (Research Paper 231). Toronto: University of Toronto Cities Centre.

Patrick, C. (2014). Aboriginal homelessness in Canada: A literature review. Toronto: Canadian Homelessness Research Network Press.

PEPSO (Poverty and Employment Precarity in Southern Ontario) Research Alliance. (2012). It's more than poverty: Employment precarity and household wellbeing. Hamilton: McMaster University.

Picture the Homeless. (2012). Banking on vacancy: Homelessness and real estate speculation. New York: Picture the Homeless.

Porter, B. (2007). Claiming adjudicative space: Social rights, equality and citizenship. In M. Young, S. Boyd, G. Brodsky \& S. Day (Eds.), Poverty: Rights, Social Citizenship, and Legal Activism. Vancouver: UBC Press.

Preston, V., Murdie, R., D’Addario, S., Sibanda, P., \& Murnaghan, M. A. (2011). Precarious housing and hidden homelessness among refugees, asylum seekers, and immigrants in the Toronto Metropolitan Area. Toronto: CERIS-The Ontario Metropolis Centre.

Rosenthal, R. (2000). Imaging homelessness and homeless people: Visions and strategies within the movement(s). Journal of Social Distress and the Homeless, 9(2), 111-126.

Sharma, N. (2006). Home economics: Nationalism and the making of "Migrant Workers" in Canada. Toronto: University of Toronto Press.

Stock, M. (2016). Ending homelessness? A critical examination of Housing First in Canada and Winnipeg. Winnipeg: Canadian Centre for Policy Alternatives Manitoba.

Suttor, G. (2015). Rental housing dynamics and lowerincome neighbourhoods in Canada (Research Paper 235). Toronto: University of Toronto Cities Centre.

Swanson, J. (2001). Poor-bashing: The politics of exclusion. Toronto: Between the Lines.

Tweddle, A., Battle, K., \& Torjman, S. (2015). Welfare in Canada, 2014. Ottawa: Caledon Institute of Social Policy.

United Nations General Assembly. (2015). Report of the 
Special Rapporteur on adequate housing as a component of the right to an adequate standard of living, and on the right to non-discrimination in this context (UN report A/HRC/31/54). New York: United Nations. Retrieved from http://www.ohchr.org/EN/HR Bodies/HRC/RegularSessions/Session31/Pages/List Reports.aspx

Waegemakers Schiff, J., \& Rook, J. (2012). Housing First: Where is the evidence? Toronto: Homeless Hub.

Walks, A. (2013). Income inequality and polarization in Canada's cities: An examination and new form of measurement (Research Paper 227). Toronto: University of Toronto Cities Centre.

YWCA Canada. (2013a). When there's no place like home: A snapshot of women's homelessness in Canada (International Women's Day bulletin, 8 March 2013). Toronto: YWCA Canada. Retrieved from http:// ywcacanada.ca/data/publications/00000058.pdf

YWCA Canada. (2013b). Housing First, women second? Gendering Housing First. Toronto: YWCA Canada. Retrieved from http://ywcacanada.ca/data/ documents/00000382.pdf

\section{About the Author}

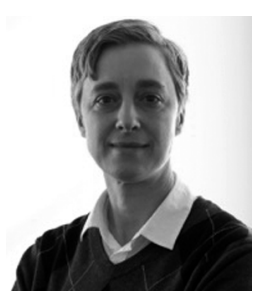

Emily Paradis has been an activist, researcher, advocate and front-line service provider with women facing homelessness for 25 years. Dr. Paradis is a Senior Research Associate at University of Toronto's Factor-Inwentash Faculty of Social Work, research manager of the Neighbourhood Change Research Partnership, member of the Right to Housing Coalition, collaborator on the National Film Board of Canada's Highrise project, co-investigator with the Canadian Observatory on Homelessness, and allymember of the Lived Experience Advisory Council. 